\title{
GAMBARAN PENGGUNAAN PARTOGRAF DIGITAL PADA PERSALINAN OLEH BIDAN DESA
}

\section{DESCRIPTION OF THE USE OF DIGITAL PARTOGRAPHS IN DELIVERY BY VILLAGE MIDWIFE}

\author{
Widya Maya Ningrum ${ }^{1 *}$, Siti Nuraeni Agustin ${ }^{2}$ \\ ${ }^{1,2}$ Universitas Galuh, Indonesia \\ Jalan R.E Martadinata No.150 Ciamis 46213, Indonesia \\ *E-mail corresponding: widyamayaningrum@gmail.com \\ (Diterima: September 2021; disetujui Oktober 2021; dipublish November 2021)
}

\begin{abstract}
ABSTRAK
Kepatuhan dalam penggunaan partograf di Puskesmas Sodonghilir masih rendah, Untuk meningkatkan motivasi bidan dalam pengisian partograf, bidan koodinator Puskesmas Sodonghilir sebagai penanggungjawab KIA di wilayah tersebut mewajibkan bidan menggunakan partograf Digital dalam pemantauan persalinan. Penelitian ini bertujuan untuk menggambarkan gambaran efektivitas penggunaan Partograf Digital oleh bidan desa di Puskesmas Sodonghilir. Metode penelitian ini adalah deskriptif. Sampel penelitian ini adalah Total Sampling, yaitu seluruh bidan desa yang ada di kecamatan Sodonghilir sejumlah 12 bidan. Distribusi Frekuensi Penggunaan Partograf Digital Oleh Bidan Di Wilayah Kerja Puskesmas Sodonghilir kategori baik sebanyak 6 orang (50\%). Diharapkan bidan meningkatkan motifvasi penggunaan partograf digital saat pemantauan persalinan.
\end{abstract}

Kata Kunci: Penggunaan, Partograf Digital, Bidan

\begin{abstract}
Compliance with the use of partographs at the Sodonghilir Health Center is still low. To increase the motivation of midwives in filling out partographs, the coordinating midwife of the Sodonghilir Health Center as the person in charge of $\mathrm{MCH}$ in the area requires midwives to use digital partographs in monitoring deliveries. This study aims to describe the effectiveness of using Digital Partographs by village midwives at the Sodonghilir Health Center. This research method is descriptive. The sample of this research is Total Sampling, namely all village midwives in Sodonghilir sub-district with a total of 12 midwives.Distribution of Frequency of Use of Digital Partographs by Midwives in the Working Area of Sodonghilir Health Center in good category as many as 6 people $(50 \%)$. It is hoped that midwives will increase their motivation to use digital partographs during labor monitoring.
\end{abstract}

Keywords: Use, Digital Partograph, Midwife

\section{PENDAHULUAN}

Partograf merupakan alat yang digunakan untuk memantau kemajuan persalinan dan membantu penolong persalinan dalam menentukan keputusan klinik. Partograf mulai digunakan pada fase aktif dan di isi secara keseluruhan. Partograf dapat meningkatkan mutu dan keteraturan pemantauan ibu dan bayi, disamping itu partograf dapat mengetahui adanya komplikasi persalinan dan menurunkan resiko terjadinya perdarahan post partum dan akan menurunkan resiko terjadinya 
persalinan macet, rupture uterin dan lain-lain (Prawirohardjo dkk, 2010).

Sampai saat ini penggunaan partograf dalam persalinan masih sangat rendah. Berdasarkan Kajian Kualitas Kesehatan Ibu dan Bayi yang dilakukan oleh Kementrian Kesehatan, WHO dan HOGSI tahun 2012 didapatkan hasil fasilitas pelayanan kesehatan yang menggunakan partograf dalam pertolongan persalinan masih rendah, yaitu $25 \%$ di Rumah Sakit, $45 \%$ di Puskesmas, dan 54\% di Klinik bersalin (Ningrum, 2019). Selain rendahnya penggunaan partograf, masih banyak bidan yang mengisi partograf tetapi tidak lengkap, hal ini tentunya sangat berdampak kepada pengambilan keputusan pada saat persalinan (Ningrum, 2019).

Dengan permasalahan yang ada terkait dengan rendahnya penggunaan partograf dalam pemantauan persalinan, di pelayanan kebidanan terdapat suatu produk inovatif yang dibuat dengan tujuan untuk mempermudah bidan dalam pengisian partograf, yaitu adanya partograf digital (Sari, 2012). Partograf digital adalah alat untuk memantau kemajuan persalinan dengan menggunakan aplikasi berbasis android mengacu kepada partograf WHO. Menjawab tantangan jaman, bahwa untuk pelayanan kebidanan, partograf digital menjadi salah satu alternatif yang dapat dipilih oleh bidan dalam pemantauan persalinan (Ningrum, 2017). Dengan adanya partograf digital diharapkan bidan lebih meningkatkan dan patuh dalam pengisian partograf.
Untuk meningkatkan motivasi bidan dalam pengisian partograf, bidan koodinator Puskesmas Sodonghilir sebagai penanggungjawab KIA di wilayah tersebut mewajibkan bidan menggunakan partograf Digital dalam pemantauan persalinan semenjak bulan Januari 2021. Dan dalam pelaksanaannya perlu dilakukan evaluasi terhadap penggunaan partograf digital di wilayah kecamatan puskesmas Sodonghilir. Terdapat 12 bidan yang telah mendapatkan pelatihan terkait pengisian partograf digital.

\section{METODE PENELITIAN}

Jenis penelitian yang digunakan dalam penelitian ini adalah jenis penelitian deskriptif, yaitu penelitian yang memberikan gambaran tentang penggunaan partograf digital. Populasi dalam penelitian ini adalah Bidan di wilayah kerja Puskesmas Sodong Hilir sebanyak 12 orang. Pengambilan sampel dengan cara total sampling.

\section{HASIL PENELITIAN DAN}

\section{PEMBAHASAN}

\section{Hasil Penelitian \\ Penggunaan Partograf Digital}

Penggunaan Frekuensi Persentase

\begin{tabular}{lcc} 
& (f) & $(\%)$ \\
\hline Kurang & 3 & 25 \\
Cukup & 3 & 25 \\
Baik & 6 & 50 \\
\hline Jumlah & 12 & 100
\end{tabular}

Berdasarkan tabel diatas dapat diketahui bahwa setengah dari responden dalam penggunaan partograf digital termasuk kategori baik sebanyak 6 responden $(50 \%)$.

\section{Pembahasan}

Hasil penelitian menunjukkan 6 responden $(50 \%)$ sudah menerapkan 
penggunaan partograf digital dengan baik. Penggunaan partograf digital ini merupakan perilaku yang menggambarkan kesiapan atau kesediaan bidan untuk memanfaatkan aplikasi partograf digital dalam melakukan pemantauan kemajuan persalinan dan pencatatan pelaporan dalam proses persalinan. Hal ini menunjukan bahwa setengah dari responden sudah mampu memanfaatkan aplikasi dengan baik dan menjadikan partograf digital ini sebagai alat dalam pemantauan kemajuan persalinan.

Dari 6 responden dengan kategori pengguaan partograf baik, hasil observasi didapatkan bahwa 10 item yang menjadi acuan dalam penggunaan partograf dilakukan sesuai dengan standar. Dimana bidan melakukan pengisian partograf digital saat pemantauan persalinan, dan pengisian partograf digital dilakukan secara lengkap dan benar serta pada saat pemantauan bidan mengambil keputusan yang tepat sesuai dengan kondisi pada saat persalinan, dan dalam pemenuhan aspek pendokumentasian bidan mencetak partograf digital sebagai bukti bahwa bidan telah melakukan pemnatauan persalinan. Sesuai dengan hasil penelitian yang dilakukan oleh Ningrum, dkk bahwa partograf digital merupakan alat pemantauan kemajuan persalinan sebagai alternatif yang dapat dipilih atau digunakan bidan saat persalinan. Semua fungsi yang ada dalam partograf digital sama dengan partograf manual. Bidan perlu menggunakan partograf saat melakukan pemantauan kemajuan persalinan.

Hal ini sesuai dengan hasil penelitian Nelvi (2009) yang berjudul "Penggunaan
Partograf dalam Pengelolaan Persalinan" yaitu penggunaan partograf dalam pengelolaan persalinan $91,2 \%$ partograf dianggap baik, yang dapat berdampak terhadap proses persalinan. dampak ini hubungannya dengan pengambilan keputusan saat memantau persalinan. dengan penggunaan partograf penolong dapat membuat keputusan apakah persalinan dapat dilakukan pertolongan atau ditujuk sesuai dengan hasil pemantauannya.

Di dalam hasil penelitian ini terdapat satu responden saat menggunakan partograf digital melakukan rujukan karena persalinan lama. Pada saat bidan melakukan pengisian data pembukaan, sistim notifikasi dalam partograf digital berupa alarm berbunyi, dengan menunjukan hasil pembukaan melewati garis waspada dan pasien harus dirujuk. Kondisi ini menunjukan bahwa partograf digital mempunyai kelebihan dibandingkan dengan partograf yang manual, dengan alarm yang berbunyi menunjukan peringatan kepada bidan untuk segera melakukan rujukan sehingga bidan bisa lebih cepat dan akurat dalam mengambil keputsan, hal ini sesuai dengan fungsinya bahwa partograf digital adalah alat untuk melakukan pengambilan keputusan klinik.

Berdasarkan hasil penelitian, terdapat 3 responden (25\%) termasuk kategori kurang dalam penggunaan partograf digital.dari hasil observasi yang dilakukan peneliti, item yang tidak dilakukan sebagai standar dalam pengisian partograf digital adalah seluruh responden tidak mencetak partograf digital. Hal ini tentunya tidak sesuai dengan aspek pendokumentasian persalinan, partograf 
Widya Maya Ningrum \& Siti Nuraeni Agustin menjadi salah satu bukti pendokumentasian dalam pemantauan persalinan. Berdasarkan hasil observasi tidak dicetaknya partograf ini dikarenakan tidak tersedianya sarana mesin cetak (printer) di tempat bidan. Bidan hanya menyimpan hasil partograf digial dalam bentuk file saja.

Hal ini sejalan dengan hasil penelitian Septasari bahwa Pelaksanaan Pendokumentasian Lembar Partograf Dalam Memonitor Persalinan merupakan hal yang sangat penting sebagai aspek legal dalam pertolongan persalinan, dari hasil penelitian didapatkan bawa $70 \%$ bidan tidak melakukan pendokumentasian persalinan dengan partograf.

Berdasarkan hasil penelitian didapatkan bawah 3 orang responden (25\%) termasuk kategori kurang dalam penggunaan partograf diigital, didapatkan data bahwa seluruh dari responden mengisi partograf digital pada saat persalinan selesai. dan 1 orang responden tidak mengisi partograf digital saat melakukan observasi. Pengisian partograf diigital sebagai alat pemantau kemajuan persalinan harus dilakukan pada saat persalinan berlangsung. Pemantauan saat persaliann dengan menggunakan partograf sangat berdampak pada pengambilan keputusan saat persalinan. Sejalan dengan hasil penelitian Hasbiah dengan judul Analisis Penerapan Partograf Dalam Asuhan Persalinan Normal (APN) didaptkan hasil sebagian besar bidan mengisi partograf setelah selesai persalinan dan hanya untuk kepentingan pencairan jampersal saja.

\section{SIMPULAN}

Berdasarkan hasil penelitian dapat disimpulkan bahwa setengah dari jumlah responden yaitu 6 orang $(50 \%)$ dalam penggunaan partograf digital pada saat persalinan di Puskesmas Sodonghilir termasuk kategori baik.

\section{DAFTAR PUSTAKA}

Prawirohardjo S, Winkjosastro H, Sumapraja S. (2010). Ilmu kebidanan. Jakarta: yayasan Bina Pustaka.

Ningrum, Solihah. (2019). Partograf digital.

Sari. (2012). Hubungan sikap dan masa bidan dengan penggunaan partograf di wilayah kerja puskesmas pekauman Banjarmasin.

Ningrum, Supriani. (2017). Gambaran penggunaan partograf pada kasus rujukan oleh bidan di ruangan Ponek RS Singaparna Medika Citra Utama. 